\title{
INTERVENSI KOGNITIF DAN PENDEKATAN RANTAI NILAI DALAM PENINGKATAN PEMANFAATAN TEKNOLOGI INFORMASI DAN KOMUNIKASI DI USAHA KECIL DAN MENENGAH DI BANDUNG
}

\author{
Ari Widyanti*), Indryati Sunaryo*) \\ Fakultas Teknologi Industri, Program Studi Teknik Industri, Institut Teknologi Bandung \\ Labtek III Jl. Ganesa 10 Bandung 40135
}

(Received: November 17, 2015 / Accepted: February 15, 2016)

\begin{abstract}
Abstrak
Pemanfaatan teknologi informasi dan komunikasi (TIK) di usaha kecil dan menengah (UKM) di Indonesia masih pada tingkat yang belum sesuai harapan. Mempertimbangkan bahwa UKM di Indonesia banyak menyerap tenaga kerja dan menyumbang pendapatan nasional yang cukup besar, serta melihat bahwa pemanfaatan TIK di banyak industri besar telah membawa peningkatan performansi yang cukup signifikan, peningkatan pemanfaatan TIK di UKM merupakan hal yang penting untuk dilakukan. Penelitian ini dilakukan dengan tujuan untuk memetakan tingkat pemanfaatan TIK di UKM dan mengaplikasikan intervensi kognitif dan pendekatan rantai nilai dalam meningkatkan pemanfaatan TIK di UKM. Pemetaan pemanfaatan TIK dilakukan melalui survey dengan menggunakan kuesioner terstruktur dan wawancara yang melibatkan 61 UKM di berbagai bidang di Bandung. Hasil pemetaan pemanfaatan TIK di UKM menunjukkan bahwa pemanfaatan TIK di UKM sebatas pada tujuan pemasaran produk dan sebatas pada penggunaan website. Kendala utama pemanfaatan TIK di UKM adalah faktor SDM terutama berkaitan dengan keterbatasan pengetahuan dan informasi. Berdasarkan hasil pemetaan, selanjutnya, intervensi dilakukan melalui edukasi/kampanye dengan materi mengenai rantai nilai pada 30 UKM yang bergerak di bidang fashion. Hasil intervensi menunjukkan bahwa level pengetahuan dan intensi/kemauan untuk menerapkan TIK di UKM selain untuk kepentingan pemasaran (misalnya untuk perancangan produk dan hubungan dengan pemasok) semakin meningkat. Implikasi dari hasil penelitian ini dibahas lebih lanjut.
\end{abstract}

Kata kunci: intervensi; rantai nilai; TIK; UKM

\begin{abstract}
The use of information and communication technology (ICT) in small and medium enterprise (SME) in Indonesia is at low level. Considering that SME in Indonesia employ a lot of people and contribute to Gross Domestic Product $(G D P)$ as well as improve performance of industries, coupled with low level of ICT use in Indonesian SME, ICT' used in SME must be increased. Therefore, this study aims to map the use of ICT in SME in Bandung, and to apply cognitive intervention and value chain approach in increasing ICT use in SME.

Mapping of ICT use in SME was conducted by survey with structured questionnaire and interview involving 61 SME in Bandung. Result shows that ICT use in SME is limited only for product marketing and is mostly using website. Main constraint of ICT use in SME is related with human resource capability in particular related with limited knowledge and information about ICT use.

Based on mapping result, intervention was conducted through education or campaign with value chain content on 30 SME in fashion. Intervention result shows that knowledge level and intention to implement ICT in SME other than marketing purpose is increasing. Implication of the results is discussed.
\end{abstract}

Keywords: intervention; value chain; ICT; SME

\section{Pendahuluan}

Usaha kecil dan menengah (UKM) merupakan sektor yang sangat diperhitungkan di Indonesia karena kontribusinya terhadap perekonomian Indonesia. Hal tersebut dapat dilihat dari peran UKM

\footnotetext{
${ }^{*}$ Penulis Korespondensi. email: widyanti@mail.ti.itb.ac.id, ryaryo@yahoo.com
}

dalam pertumbuhan ekonomi nasional, produk domestik bruto (PDB) yang diciptakan, nilai tambah nasional, serta penyerapan tenaga kerja. Hal ini sejalan dengan laporan World Summit on the Information Society (WSIS, 2013) bahwa pada negara-negara berkembang, UKM merupakan sumber utama pendapatan, landasan wirausaha, dan menyerap tenaga kerja sekitar $65 \%$ dari total tenaga 
kerja di 130 negara di dunia. Selain itu, UKM telah terbukti dapat bertahan pada saat terjadinya krisis ekonomi di Indonesia dibandingkan dengan industri skala menengah dan besar.

Dalam menghadapi persaingan global, UKM dituntut untuk melakukan upaya guna meningkatkan daya saingnya. Salah satu faktor penting yang akan menentukan daya saing UKM adalah teknologi informasi dan komunikasi (TIK). Penggunaan TIK di industri menengah dan besar telah terbukti dapat meningkatkan transformasi bisnis melalui kecepatan, ketepatan dan efisiensi pertukaran informasi dalam jumlah yang besar), terutama di negara maju (UNDP, 2007). Sebaliknya, pemanfaatan TIK di UKM negara berkembang menunjukkan hal yang tidak menggembirakan yaitu penggunaan TIK yang sangat terbatas, misalnya di India (FICCI, 2012), Oman (Ashrafi and Murtaza, 2008) dan Cina (Fong, 2011). Secara spesifik, Fong mengatakan bahwa permasalahan dalam pemanfaatan TIK di Cina adalah faktor finansial dan sumber daya manusia. Di negara berkembang di luar Asia, gambaran yang sama juga ditemukan. Sebagai contoh, penelitian yang dilakukan oleh Esselaar dkk (2007) mengenai pemanfaatan TIK di beberapa negara di Afrika, menunjukkan beberapa faktor yang menghambat adopsi dan pemanfaatan TIK di negara-negara Afrika diantaranya permasalahan infrastruktur dan jaringan, masalah finansial, kurangnya pengetahuan dan kesadaran akan pentingnya TIK.

Gambaran yang sama mengenai rendahnya pemanfaatan TIK di UKM juga dijumpai di Indonesia (Rahmana, 2009). Menurut hasil Sensus Ekonomi tahun 2006, UKM di sektor industri manufaktur yang menggunakan komputer hanya $1 \%$ dari total UKM yang ada di Indonesia. UKM yang memanfaatkan jaringan internet tidak lebih dari $0.2 \%$ dari total UKM yang ada. Hasil penelitian lain menunjukkan pemanfaatan TIK pada UKM furniture dan handicraft yang hanya berkisar pada angka $20 \%$ (Noor, 2006). Lebih jauh, Ruswendi (2010) menyatakan bahwa penggunaan TIK di UKM Indonesia sangat beragam, mulai dari penggunaan dasar (basic communications) seperti radio, telepon, dan fax; teknologi informasi dasar (basic information technology) seperti komputer yang dilengkapi dengan software dasar; komunikasi tingkat lanjut (advanced communications) seperti email, internet; hingga tekonologi informasi tingkat lanjut (advanced information technology) seperti penggunaan komputer desktop yang dilengkapi dengan softrare Enterprise Resource Planning, inventory management dll. Lebih jauh Ruswendi menyatakan bahwa mayoritas penggunaan TIK di UKM adalah untuk penggunaan dan teknologi informasi dasar.

Berlainan dengan sejumlah penelitian yang memetakan pemanfaatan TIK di UKM di Indonesia, penelitian untuk melihat faktor yang menyebabkan rendahnya pemanfaaan TIK di UKM di Indonesia sangat terbatas. Salah satu penelitian yang ada adalah yang dilakukan oleh Sarosa dan Zowghy (2004) yang menyatakan bahwa kegagalan adopsi TIK adalah karena kurangnya kesadaran (awareness) UKM akan fungsi TIK secara keseluruhan dalam peningkatan kinerja UKM serta pemanfaatan TIK yang sangat terbatas untuk keperluan tertentu saja.

Selama ini, upaya yang dilakukan untuk meningkatkan pemanfaatan TIK di UKM masih sangat terbatas dan hanya terbatas pada aspek teknis. Pemerintah misalnya melalui Kementerian informasi dan telekomunikasi mengadakan kegiatan bimbingan teknis/bimtek pemanfaatan tekonologi internet untuk kegiatan produktif (http://balitbang.kominfo.go.id). Salah satu BUMN di bidang telekomunikasi menghadirkan program Indonesia Digital Enterpreneur (INDIPreneur) yang dimaksudkan untuk membekali para pelaku UKM dengan pengetahuan mengenai implementasi TIK di bidang pemasaran dan e-commerce serta memberikan kemampuan untuk menjalankannya (www.indipreneur.smartbisnis.co.id). Kalangan akademisi juga melakukan usaha untuk meningkatkan pemanfaatan TIK di UKM misalnya melalui Workshop digital marketing (www.telkomuniversity.ac.id). Namun perlu digarisbawahi bahwa usaha-usaha tersebut masih terbatas pada pembekalan teknis untuk keperluan pemasaran produk atau jasa.

Di negara lain, berbagai upaya yang bersifat non teknis dilakukan dalam meningkatkan pemanfaatan TIK di UKM. Di Cina, upaya pemanfaatan TIK di UKM dilakukan melalui dukungan keuangan, konsultasi, dan pelatihan (Fong, 2011). Contoh lainnya, Harindranath (2008) menyatakan bahwa penggunaan IT di UKM di Inggris ditentukan oleh faktor biaya dan efisiensi serta faktor pertambahan nilai (added value).

Lebih jauh, Ghobakhlo, dkk. (2011) mengembangkan suatu kerangka (frame work) yang menyatakan bahwa adopsi TIK dipengaruhi oleh faktor eksternal dan faktor internal. Faktor eksternal meliputi pelanggan, pemerintah, vendor, dan pesaing. Sedangkan faktor internal meliputi manajer, staf, penanggung jawab TIK, serta karakteristik dan perilaku manusia dan organisasi.

Faktor perilaku sebagaimana yang dinyatakan oleh Ghobakhlo dkk (2011) terbukti memegang peran penting dalam peningkatan performansi organisasi dan individual, terutama melalui perubahan perilaku yang dilakukan melalui intervensi. Intervensi perilaku telah terbukti banyak berhasil dalam mengubah intensi maupun perilaku sesorang sesuai tujuan intervensi. Misalnya, intervensi perilaku yang dilakukan oleh Widyanti $\operatorname{dkk}(2013)$ dalam rangka merubah intensi dan preferensi untuk mengkonsumsi makanan pokok non nasi telah berhasil memberikan perubahan.

Intervensi perilaku didasarkan pada Theory of Planned Behavior (TPB; Ajzen, 1987). Teori ini menjelaskan bahwa pada dasarnya perilaku dapat 
diprediksikan berdasarkan faktor yang mempengaruhinya. Dalam pelaksanaan intervensi, terdapat tiga aspek pada tingkatan yang berbeda, yang dapat dipengaruhi oleh pelaksanaan intervensi. Aspek tersebut adalah aspek cognitive, affective, dan conative (Fishbein, 1967). Lebih jauh lagi, Pike and Ryan (2004) memberikan definisi untuk ketiga aspek tersebut. Menurut Pike dan Ryan, cognitive meliputi kesadaran (awareness), pengetahuan (knowledge), atau kepercayaan (beliefs). Affective mengacu pada perasaan individu terhadap suatu obyek apakah disukai atau tidak atau netral (Fishbein). Conative analog dengan perilaku itu sendiri.

Faktor lain yang mempengaruhi adopsi dan pemanfaatan TIK di UKM menurut Harindranath (2008) adalah faktor pertambahan nilai (added value). Dalam hal ini, jika TIK selain untuk aspek pemasaran dirasakan perlu dan akan memberikan nilai tambah bagi UKM, maka besar kemungkinan UKM akan memanfaatkan TIK dengan lebih efektif dan optimal. Pertambahan nilai dalam suatu proses produksi dapat dilihat dari rantai nilai (value chain) yang didefinisikan sebagai sekumpulan aktivitas bisnis dimana di setiap tahapan/langkah dalam aktivitas bisnis tersebut menambahkan nilai/value atau kemanfaatan terhadap barang dan jasa organisasi yang bersangkutan (Porter, 1988), sebagaimana dapat dilihat pada gambar 1. Lebih jauh lagi, beberapa penelitian juga menunjukkan pentingnya mengintegrasikan TIK dan value chain dalam meningkatkan performansi dan produktivitas industry (misalnya USAID, t.t; McCormick \& Onjala, 2007).

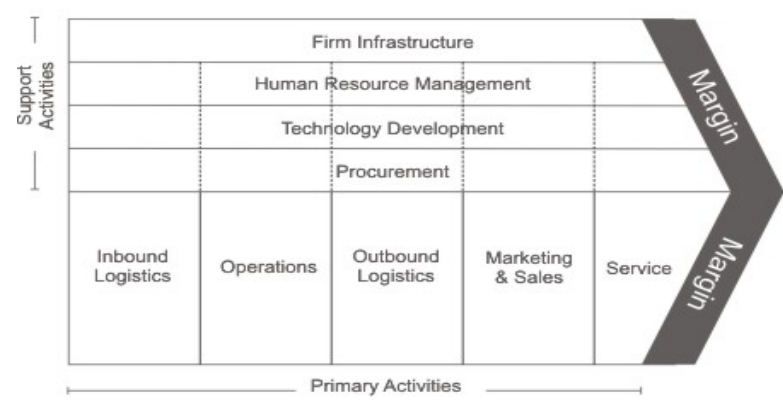

Gambar 1. Rantai nilai produksi (value chain) (sumber : Porter, 1988)

Upaya peningkatan adopsi dan pemanfaatan TIK di Indonesia harus dilakukan mengingat manfaat TIK yang dapat mendukung kinerja dan meningkatkan produktivitas UKM. Penelitian ini dilakukan dengan tujuan memetakan pemanfaatan TIK di UKM di Bandung serta mengaplikasikan intervensi kognitif dan rantai nilai sebagai upaya meningkatkan pemanfaatan TIK di UKM Bandung. Pendekatan perilaku terhadap UKM sebagai satu terobosan baru dalam peningkatan adopsi dan pemanfaatan TIK di UKM perlu diterapkan karena adopsi dan pemanfaatan TIK di UKM sangat ditentukan oleh perilaku UKM (dalam hal ini pemilik atau pihak yang berkompeten dengan TIK). Melihat

Jurnal Teknik Industri, Vol. XI, No. 2, Mei 2016 bahwa TIK di UKM selama ini penggunaannya terbatas pada administrasi dan pemasaran, pendekatan rantai nilai yang menekankan integrasi semua proses dan aktivitas bisnis dan produksi mutlak diperlukan sehingga pemanfaatan TIK di UKM Indonesia akan semakin meningkat. Oleh karena itu, pendekatan rantai nilai akan diaplikasikan dalam penelitian ini.

\section{Metode Penelitian}

Penelitian ini dilakukan dengan menggunakan metode survey untuk memetakan pemanfaatan TIK di UKM Bandung dan metode intervensi kognitif untuk mengaplikasikan pendekatan rantai nilai (value chain) dalam meningkatkan pemanfaatan TIK di UKM. Pemetaan dilakukan dengan melibatkan 61 UKM di Bandung sebagai responden yang terdiri dari11 UKM di bidang kuliner, 40 UKM bidang fashion, 5 UKM bidang otomotif, dan 5 UKM bidang pendidikan. Responden merupakan UKM yang ratarata telah beroperasi selama 11 tahun $($ stdev $=9.1$ thn). Responden dipilih dengan menggunakan sampling secara acak (random sampling). Pengambilan data dilakukan dengan menggunakan kuesioner dan wawancara terstruktur dengan pemilik UKM. Pertanyaan yang diajukan meliputi: apakah UKM sudah menggunakan dan memanfaatkan TIK dalam bisnisnya; jika UKM sudah memanfaatkan TIK, sejauh mana pemanfaatan TIK di UKM tersebut dikaitkan dengan tahapan proses bisnis; jenis peralatan TIK apa saja yang digunakan oleh UKM; dan hambatan apa saja yang menyebabkan UKM belum memanfaatkan TIK yang belum optimal.

Intervensi kognitif dan pendekatan rantai nilai dilakukan melalui media edukasi terhadap 30 perusahaan fashion menjadi responden pada tahap intervensi. Lama beroperasi perusahan-perusahaan terebut adalah 5.8 tahun (stdev=4.7 tahun). Surveyor datang ke UKM sambil melakukan wawancara terhadap kendala pemanfaatan TIK di UKM. Wawancara dilanjutkan dengan memberikan penjelasan bahwa TIK dapat digunakan tidak hanya untuk keperluan pemasaran atau berhubungan dengan konsumen, melainkan juga untuk hal di luar pemasaran sesuai dengan konteks rantai nilai. Penjelasan diberikan melalui media laptop berupa slide power point, kurang lebih selama 20 menit. Kepada responden di UKM diberikan penjelasan mengenai pemanfaatan TIK dan aplikasinya untuk kepentingan logistik, operasi/produksi, pemasaran, dan pelayanan/service. Untuk logistik, penjelasan yang diberikan meliputi hubungan dengan pemasok, aplikasi softare untuk peramalan berkaitan dengan pemasok. Untuk produksi, penjelasan diberikan berkaitan dengan keperluan dan rencana desain, penjadalan produksi.

\section{Hasil}

Gambaran penggunaan TIK di UKM yang disurvey menunjukkan bahwa UKM pada umumnya 
menggunakan perangkat telepon dan komputer sebagaimana dapat dilihat pada tabel 1. Penggunaan komputer sebatas untuk aplikasi dasar misalnya membuat laporan, dan untuk akses internet, khususnya melalui web.

Tabel 1. Perangkat TIK yang digunakan UKM

\begin{tabular}{|c|c|}
\hline $\begin{array}{lll}\begin{array}{l}\text { Perangkat } \\
\text { digunakan }\end{array} & \text { TIK yang } \\
\end{array}$ & Persentase $(\%)$ \\
\hline Telepon & 9.8 \\
\hline Komputer & 11.5 \\
\hline Telepon dan Komputer & 78.7 \\
\hline
\end{tabular}

Dari 61 UKM yang disurvey, pemanfaatan TIK paling utama adalah untuk berhubungan dengan pamasok dan berhubungan dengan konsumen. Secara rinci, penggunaan TIK di UKM dapat dilihat pada tabe1 2.

Tabel 2. Pemanfaatan TIK di UKM di Bandung

\begin{tabular}{|c|c|}
\hline Pemanfaatan TIK & Persentase (\%) \\
\hline $\begin{array}{l}\text { Pencarian informasi } \\
\text { pasar }\end{array}$ & 7.1 \\
\hline $\begin{array}{l}\text { Keperluan informasi } \\
\text { desain }\end{array}$ & 25.0 \\
\hline Pengembangan produk & 10.8 \\
\hline Pengadaan & 7.1 \\
\hline Produksi & 3.6 \\
\hline Pelayanan distribusi & 3.6 \\
\hline Pemasaran & 46.4 \\
\hline
\end{tabular}

Pada tahapan selanjutnya dan untuk mendapatkan gambaran yang lebih representatif, dilakukan survey dengan fokus pada UKM bidang fashion yang merupakan jumlah UKM terbesar dari responden penelitian pada tahap awal, dan juga merupakan UKM yang banyak dijumpai di Bandung. Hasil survey lebih lanjut menunjukkan bahwa UKM fashion hanya mengalokasikan biaya TIK sebesar $1.38 \%$ dari total asset yang mereka miliki. Nilai ini menunjukkan angka yang sangat kecil, terutama jika dikaitkan dengan fakta bahwa biaya bukanlah merupakan kendala utama dalam pemanfaatan TIK di UKM fashion, melainkan sumber daya manusia (SDM) lah yang menjadi kendala utama sebagaimana bisa dilihat pada tabel 2 . Kendala pada SDM ini terutama berkaitan dengan keterbatasan informasi dan pengetahuan.

Tabel 3. Kendala dalam pemanfaatan TIK di UKM fashion

\begin{tabular}{ll}
\hline $\begin{array}{l}\text { Kendala dalam } \\
\text { pemanfaatan TIK di UKM }\end{array}$ & Persentase (\%) \\
\hline Biaya & 7.1 \\
Waktu & 25.0 \\
SDM & 60.7 \\
Teknis & 7.1 \\
\hline
\end{tabular}

Wawancara lebih jauh dengan responden menunjukkan bahwa kendala SDM yang dimaksud adalah berkaitan dengan terbatasnya pemahaman mengenai IT oleh pelaku UKM. Terbatasnya pemahaman yang dimaksudkan antara lain: IT diasumsikan hanya bisa digunakan untuk aspek pemasaran, selain itu, pemahaman pelaku UKM mengenai pemanfaatan IT hanya terbatas pada kegiatan browsing internet dan online shoping. Hasil survey dan wawancara digunakan sebagai dasar intervensi.

Oleh karena itu, sesuai dengan teori Antecedent - Behavior - Consequence (ABC), behavior yang harus diubah adalah pada level pengetahuan (cognitive) dan kemauan/intensi (affective). Peningkatan level pengetahuan (cognitive) dilakukan melalui metode edukasi sehingga pemahaman pelaku UKM akan manfaat IT semakin meningkat. Sedangkan untuk meningkatkan kemauan/intensi (affective), dilakukan dengan menunjukkan success story dari pemanfaatan IT di UKM. Oleh karena itu, disusunlah metode intervensi yang sesuai untuk UKM fashion berdasarkan studi literatur dan mempertimbangkan aspek teknis yang sesuai, yaitu metode edukasi/kampanye/penyampaian materi. Materi intervensi yang diberikan meliputi :

- materi tentang rantai nilai (value chain) mulai dari pemasok, produksi, pemasaran, dan service/pelayanan.

- Aplikasi TIK dalam rantai nilai

Contoh materi intervensi dapat dilihat pada gambar 2.

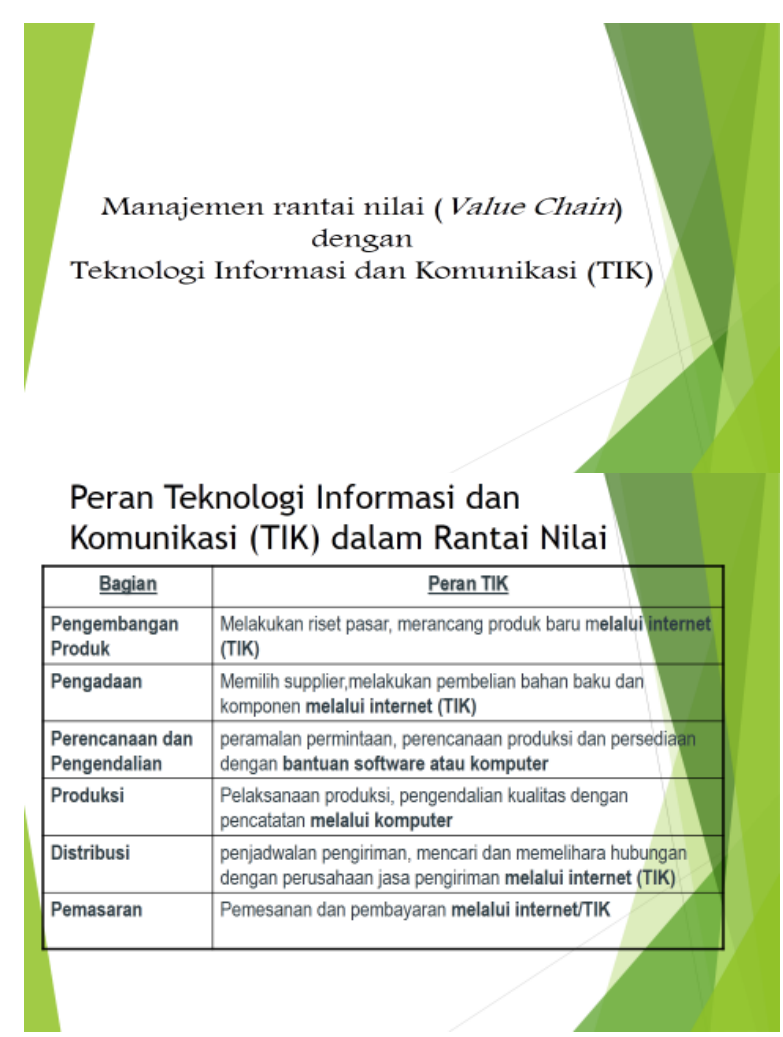

Gambar 2. Contoh materi intervensi pemanfaatan TIK di UKM 
Intervensi diberikan dalam bentuk pemaparan slide presentasi di laptop yang diberikan dalam waktu lebih kurang 20 menit untuk masing-masing UKM. Setelah intervensi dilakukan, kepada UKM diberikan pertanyaan tambahan melalui wawancara mengenai keinginan/intensi UKM untuk mengadopsi dan memanfaatkan TIK lebih dari yang sekarang mereka terapkan. 28 UKM menyatakan bahwa mereka memiliki keinginan untuk menggunakan TIK lebih jauh, sedangkan 2 UKM menyatakan baha mereka tidak memiliki keinginan untuk memanfaatkan TIK lebih jauh, cukup dengan kondisi yang ada sekarang.

Berkaitan dengan materi intervensi, dalam contoh di atas, aspek pengembangan produk yang tidak termasuk dalam komponen value chain Porter dimasukkan dalam materi intervensi, karena hasil survey dan wawancara menunjukkan bahwa aspek pengembangan produk merupakan aspek yang penting menurut pelaku UKM.

\section{Pembahasan}

Level pemanfaatan TIK di UKM Bandung yang menjadi responden dalam penelitian ini masih relatif rendah yaitu mayoritas masih menggunakan perangkat handphone dan komputer dengan aplikasi dasar misalnya dengan menggunakan aplikasi internet untuk website. Level pemanfaatan TIK di UKM Bandung ini sesuai dengan yang dinyatakan Rusendi (2010) yaitu di level 2 (basic information technology). Kondisi ini sejalan dengan kondisi UKM di bidang yang lain di Indonesia pada umumnya, misalnya UKM foto copy di Lampung (Khristianto, 2012) yang menunjukkan hanya $60 \%$ UKM yang memiliki komputer yang terutama digunakan hanya untuk membuat laporan. Penelitian yang sama yang dilakukan oleh Wahid (2007) menunjukkan bahwa UKM bidang furniture di Jepara hanya $20 \%$ yang menggunakan komputer.

Pemilihan UKM di bidang fashion sebagai obyek penelitian dalam aplikasi intervensi kognitif dan pendekatan rantai nilai didasarkan pada kondisi bahwa UKM ini banyak terdapat di Bandung dan merupakan salah satu bidang ekonomi kreatif di Bandung yang sedang diupayakan peningkatan performansinya karena banyak menyerap tenaga kerja dan menggerakkan sektor perekonomian (kadinbandung, 2014).

Rata-rata UKM dalam studi ini hanya mengalokasikan $1.54 \%$ dari total asset untuk investasi di TIK. Hal ini dikarenakan pemahaman UKM tentang manfaat TIK dalam pengembangan bisnisnya masih terbatas untuk pemasaran. Kondisi ini sejalan dengan penelitian yang dilakukan oleh Roosdhani dkk (2014) di berbagai UKM di Jepara.

Kendala utama yang dihadapi UKM dalam pemanfaatan TIK adalah keterbatasan pengetahuan dan informasi SDM mereka tentang pemanfaatan TIK di UKM. Oleh karena itu, intervensi berupa pemberian materi/kampanye dilakukan untuk merubah level pemahaman dan intensi dari UKM untuk menggunakan TIK sesuai dengan konteks rantai nilai. Intervensi terbukti menunjukkan peningkatan level pemahaman dan intensi/kemauan untuk menggunakan TIK lebih luas sesuai konteks rantai nilai.

Intervensi yang dilakukan melalui penyampaian materi tentang rantai nilai dan kegunaan TIK pada masing-masing rantai nilai ternyata membuat $97 \%$ dari UKM (26 dari 28 UKM) memiliki intensi/keinginan untuk menggunakan TIK lebih jauh terutama berkaitan dengan hubungan dengan pemasok, produksi, distribusi dll (yang sejalan dengan rantai nilai produksi). Sebanyak 2 UKM menyatakan bahwa mereka tidak memiliki keinginan untuk menggunakan TIK di UKM mereka lebih jauh karena merasa tidak membutuhkan. Hal ini menunjukkan baha

Jika selama ini banyak penelitian berhenti pada pembahasan penggunaan TIK di UKM yang masih rendah, permasalahan utama yang terjadi kemungkinan besar adalah kurangnya pemahaman mengenai manfaat TIK terutama jika dikaitkan dengan rantai nilai. Untuk itu, langkah pertama yang harus dilakukan oleh stake holder UKM yang berkepentingan dengan penggunaan TIK di UKM adalah dengan meningkatkan pemahaman tentang TIK dan rantai nilai untuk akhirnya menumbuhkan intensi/kemauan untuk meningkatkan pemanfaatan TIK di UKM. Hal ini mendukung hasil penelitian sebelumnya yang menunjukkan bahwa perubahan perilaku akan mempengaruhi level adopsi dan pemanfaatan TIK di UKM, dan bahwa pemahaman mengenai pertambahan nilai (added value) juga akan mempengaruhi level adopsi dan pemanfaatan TIK di UKM (Ghobakhlo dkk, 2011).

Penelitian ini memiliki beberapa keterbatasan. Pertama, terutama karena masalah teknis dan waktu, perubahan penggunaan TIK setelah intervensi belum/tidak dapat dilihat atau dimonitor lebih jauh. Padahal hal ini penting untuk melihat perubahan perilaku UKM terhadap pemanfaatan TIK setelah intervensi. Kedua, intervensi kognitif dan pendekatan rantai nilai diterapkan hanya untuk UKM bidang fashion. Pendekatan ini perlu diterapkan di UKM bidang lainnya untuk melihat apakah perubahan kognitif dan intensi setelah intervensi juga akan didapatkan, sehingga hasil penelitian ini dapat digeneralisasi untuk bidang UKM yang lainnya.

\section{Ucapan Terima Kasih}

Penelitian ini didanai oleh JICA dalam skema Proyek Pengembangan ITB III tahun anggaran 2014.

\section{Daftar Pustaka}

Ajzen, I. (1987). From intention to action: A theory of planned behavior. In J. Kuhl and $\mathrm{J}$. Beckman, eds. Action-Control: from cognition to behavior. Heidelberg, Germany: Springer, pp. 11-39. 1985 
Ashrafi, R. and Murtaza, M. (2008). Use and Impact of ICT on smes in Oman." The Electronic Journal Information Systems Evaluation. 11(3), pp. $125-138$.

Esselaar, S., Stork, C., Ndiwalana, A., and DeenSwarray, M. (2007). ICT Usage and Its Impact on profitability of SMEs in 13 African Countries, Information Technologies and International Development, 4(1), pp. 87-100.

Federation of Indian Chamber of Commerce and Industry (FICCI). 2012. Usage of Information and Communication Technology (ICT) tools by Indian SMEs and its impact on their business. Technical report.

Fishbein, M. And Ajzen, I., (1975). Belief, attitude, intention, and behavior: An introduction to theory and research. Reading, MA: AddisonWesley.

Fong, M, L. (2011). Chinese SMEs and Information Technology Adoption. Issues in informing science and information technology, 8, pp. 313-322.

Ghobakhlo, M., Sabouri, M.S., Hong, T.S., Zulkifli, N. (2011). Information technology adoption in small and medium-sized enterprises; an appraisal of to decades literature. Interdisciplinary journal of research in business. 1(7), 53-80.

Harindranath, G., Dyerson, R., and Barnes, D. (2008). ICT adoption and use in UK SMEs: a failure of initiatives? The electronic Journal Information Systems Evaluation, 11(2), 91-96.

http://balitbang.kominfo.go.id/balitbang/blog/2014/0 4/17/bimtek-literasi-tik-pemanfaatan-internetuntuk-kegiatan-produktif-bagi-pelaku-usahakecil-menengah-ukm/. Akses 25 Agustus 2015.

http://www.indipreneur.smartbisnis.co.id/public/page .html. Akses 25 Agustus 2015.

http://www.telkomuniversity.ac.id/article/dosen-tel-udorong-ukm-sadar-tik. Akses 25 Agustus 2015.

Kadinbandung. (2014). Pemkot Bandung terapkan OVOP. Dapat diakses di http://kadinbandun.org. Akses 10 Septermer 2015.

Khristianto, W. 2012. Penggunaan Teknologi Informasi di Usaha Kecil dan Menengah (Studi Pada Usaha Kecil Menengah di Wilayah Gedong Meneng) -Proceeding FISIP UNILA 2012.

McCormick, D., Onjala, J. 2007. Methodology for value chain analysis in ICT industry frameworks for the study of Africa. Working paper. African Economic Research Consortium (AERC)
Pike, S. and Ryan, C. (2004). Destination Positioning Analysis through a Comparison of Cognitive, Affective, and Conative Perceptions. Journal of Travel Research. 42: 333-342.

Porter, M. E. (1998). Competitive Advantage; Creating and Sustaining Superior. New York: Free Press.

Prastowo, B.N. (2011). Intervensi Pemerintah pada Penggunaan Teknologi Informasi dan Komunikasi. dapat diakses di http://ploworks.wg.ugm.ac.id/public.php?filei $\mathrm{n}=$ newsandartikel=6E28932725DA002F. akses 10 Februari 2014.

Rahmana, A. (2009). Peranan teknologi informasi dalam peningkatan daya saing usaha kecil menengah. Seminar Nasional Aplikasi Teknologi Informasi, Yogyakarta, 20 Juni 2009, hal. 11-19.

Roosdhani, M. R., Wibowo, P.A., Widiasuti, A. (2014). Analisis tingkat penggunaan teknologi informasi dan komunikasi pada usaha kecil menengah di kab. Jepara. Jurnal Dinamika Ekonomi \& Bisnis. 9 (2): 89-104.

Ruswendi, W. (2010). Difusi free open source software (foss) untuk koperasi, usaha kecil dan menengah (kukm). Laporan penelitian.

Sarosa, S., and Zowghi, D. (2004). Recover from information system failure:An Indonesian case study. Sidney: University of Technology Sidney.

USAID. t.t. Integrating ICT into value chain development. Briefing paper.

United Nation Development Program (UNDP) (2007).dapat diakses di www.undp.org akses 10 Februari 2014.

Wahid, F., and Iswari, L. (2007). Adopsi Teknologi Informasi Oleh Usaha Kecil dan Mengengah di Indonesia. Seminar Nasional Aplikasi Teknologi Informasi (SNATI) 2007 (Vol. 2007, pp. 75-79).

Widyanti, A. Soenaryo, I., and Yasunari, A.D. (2014). Reducing the dependency on rice as staple food in Indonesia-a behavior intervention approach. ISSAAS journal. 20 (1), 93-103.

World Summit on the Information Society (WSIS, 2013). dapat diakses di www.wordsummit2013.org akses 10 Februari 2014. 